\title{
SUPPORT TO THE LATVIAN FISHERY SECTOR THROUGH THE EU FINANCIAL INSTRUMENTS
}

\author{
Inese Biukšāne \\ Institute of Agricultural Resources and Economics, Latvia \\ inese.biuksane@inbox.lv
}

\begin{abstract}
Latvia, just like many other EU member states, receives multiannual financial support through the EU financial instruments for implementation of the common policies by the EU. The support is aimed at the priorities set at the level of the EU and is adapted to the peculiarities of each member state's sphere. The aim of the study is to evaluate the importance of the support, provided by the EU financial instruments, for the development of Latvian fishery sector. The analysis was made on the basis of the available data and their quality. As a result of the study, the author found out that in the planning periods of 2004 - 2006, 2007 - 2013 and 2014 - 2020, for the development of fishery sector in Latvia the support of several EU financial instruments was available. Development of fishery sector is significantly impacted by the availability of the financial support through the EU financial instruments and use thereof. Considering the dependence of the fishery sector on the sustainability principles coordinated at the level of EU, corresponding fishery possibilities, and considering the increase of global competitiveness in the world's markets, the strengthening of fishery's competitiveness plays a significant role in the facilitation of the Latvian economy.
\end{abstract}

Key words: Common Fisheries Policy, EU financial instruments, financial support, fishery sector.

\section{Introduction}

The length of the Latvian border is $1836 \mathrm{~km}, 27 \%$ or $494 \mathrm{~km}$ of which is the length of seacoast, constituting $0.7 \%$ of the total EU shoreline of $66000 \mathrm{~km}$ (European Commission, 2014). The territorial waters of the Baltic Sea up to 12 nautical miles from the coastline, as well as economic zone and 28 thousand $\mathrm{km}^{2}$ area of continental shelf are in the jurisdiction of the country (Agriculture Ministry, 2014).

Latvia has the possibility of fishing in the Baltic Sea and the Gulf of Riga, based on the long-term study of environment and fish resources at the national and international level. According to the international contracts concluded by Latvia, there are possibilities of fishing also in the economic zones of other countries and regions encompassed by international conventions (Finance Ministry, 2003). High-seas fisheries take place in the areas confirmed by the Northwest Atlantic Fisheries Organization (NAFO), Northeast Atlantic Fisheries Commission (NEAFC) and Fishery Committee for the Eastern Central Atlantic (NEAFC) (European Commission, 2014).

Fishery sector is closely related to the rational and sustainable use of country's economic zone and territorial waters as well as living natural resources in the internal bodies of surface water and preservation of biological diversity (Finance Ministry, 2003). The Baltic Sea is one of the youngest seas in the world and it is one of the biggest brackish water areas, which is also recognized to be one of the dirtiest seas in the world (World Wide Fund for Nature, 2005). Since the Baltic Sea has a unique ecosystem, determined by its particular geographical and hydromorphological conditions (European Commission, 2014), it requires sustainable and rational management in order to have a favourable influence on the development of fishery sector.
To implement the Common Fisheries Policy (CFP), Latvia just like other EU member states receives multiannual financial support through the EU financial instruments. The support is aimed at the priorities set at the level of the EU and is adapted to the peculiarities of each member state's sphere. The aim of the support, provided by these EU financial instruments, is to facilitate competitive, sustainable, in terms of environment, economically viable and socially responsible, fishing (European Parliament and Council, 2014). Provision and allocation of purposeful support is important for the advancement of fishery sector's development (European Parliament and Council, 2013). Since the support provided by the EU financial instruments is available to the participants of the fishery sector also for the development of other spheres, which influences their common economic activity and development, it is important to gather the information also about the importance of these financial instruments.

The aim of the research was to evaluate the importance of the support provided by the EU financial instruments in the development of the Latvian fishery sector. To reach the aim, the following work tasks were set: 1) to analyze the support provided to the participants of the Latvian fishery sector by the EU financial instruments and the use thereof in the planning periods of 2004 - 2006, 2007 - 2013 and $2014-2020 ; 2)$ to evaluate the development of the Latvian fishery sector.

Novelty of the research - the first research broadly reflecting and analyzing the support, provided to the Latvian fishery sector by the EU financial instruments, in connection with its general development within the planning periods of 2004 - 2006, 2007 - 2013 and $2014-2020$. The obtained results provide an opportunity to the institutions involved in formation 
and implementation of fisheries policy, entrepreneurs and researchers to better understand the scope of the support provided by the EU financial instruments and its importance in the development of the Latvian fishery sector.

The author has reflected the results of the research in the article; however, more detailed and wider analysis of the results is available in the research called 'FAP Investments in Fishery to Achieve Goals of CFP' ('ZRP ieguldījumi zvejniecībā KZP mērķu sasniegšanai') funded by the Ministry of Agriculture of the Republic of Latvia.

\section{Materials and Methods}

To obtain information about the support provided by the EU financial instruments to the Latvian fishery sector in the planning periods of $2004-2006,2007$ 2013 and 2014 2020, first of all the author identified the participants of the fishery sector pursuant to the data in the Central Statistical Bureau (CSB) (Central Statistical Bureau, 2018), Latvian Fisheries Integrated Control and Information System (LFICIS) (Agriculture Ministry, 2018) and Information System of the Rural Support Service (Rural Support Service, 2017).

According to the compiled list, the author requested information from the Ministry of Finance (MF), Ministry of Environmental Protection and Regional Development (MEPRD), Development Financial Institution "Altum" (ALTUM) and "Environmental Investment Fund" Ltd. (LEIF) about the following EU financial instruments: European Regional Development Fund (ERDF), European Social Fund (ESF), Cohesion Fund (CF), LatvianSwiss Cooperation Program (LSCP), European Economic Area Financial Mechanism (EEA FM), Norwegian Financial Mechanism (NFM), Norwegian Government Bilateral Financial Instrument (NBFI), European Agricultural Guidance and Guarantee Fund (EAGGF), European Agricultural Fund for Rural Development (EAFRD), Latvian Guarantee
Agency (LGA) financial instruments, Climate Change Financial Instrument (CCFI), European Territorial Cooperation Programmes (ETC), Emissions Quota Auctioning Instrument (EQAI), and others. The RSS provided the author with the information about the Financial Instrument for Fisheries Guidance (FIFG), European Fisheries Fund (EFF) and European Maritime and Fisheries Fund (EMFF).

The analysis includes the total funding (public (EU financial instruments and state) funding and private co-funding) in the planning periods of 2004 2006, 2007 - 2013 and 2014 - 2020 (from May 2004 until August 2017). The author analyzed information about 1299 projects with the status "confirmed", "supervision started" and "closed". Availability and quality of data determined the period from $2005-$ 2016 for evaluation of the general situation in the Latvian fishery sector.

The qualitative and quantitative research methods were used in the study, including the general scientific research methods, statistical research methods, mathematical methods and sociological research methods. The author mostly applied the methods of analysis and synthesis in elaboration of conclusions. Microsoft Excel, Microsoft PowerPoint and IrfanView program were used in processing and the analysis of the study results.

\section{Results and Discussion}

EU financial instruments support

In 2004 - 2006, 2007 - 2013 and $2014-2020$ planning periods, the fishery sector received the support in amount of EUR 161.35 million from the several EU financial instruments: EAGGF, ERDF, FIFG, EFF and EMFF, including state and private cofunding (Figure 1).

From the total provided support, $86 \%$ was the public funding, but the other $14 \%$ - private cofunding. The greatest support was provided through the EFF with government co-funding - 51\%, and
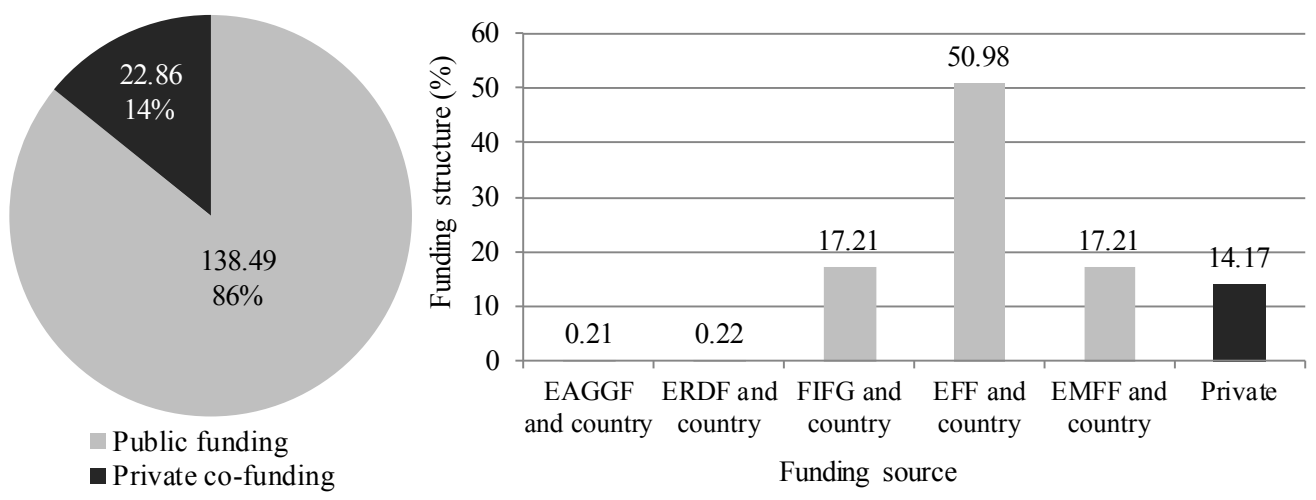

Figure 1. Structure of the total funding (A) and source of funding (B) to the participants of the fishery sector in the planning period of 2004 - 2006, 2007 - 2013 and 2014 - 2020 (EUR million, \%) (author's calculations based on data from Finance Ministry, 2017; Rural Support Service, 2017). 


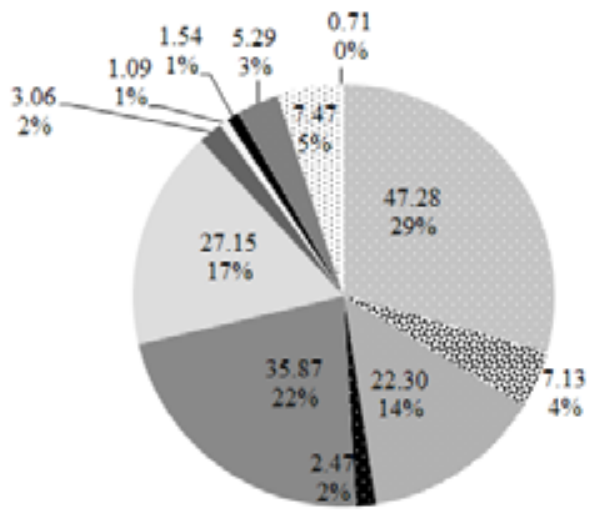

- Compensations to the owners of fishing vessels

* Compensations to the crew members of fishing vessels

E Support to producers' organizations

- Modernization of fishing fleet

= Modernization of fishing ports, wharves and dischar ging places

Modernization of process of fish storage and processing

= Acquisition of new markets

Development of territories important for fisheries

- Supplementation of eel stock.

= Aquaculture modernization

Aquatic environment activities in aquaculture

Development of other types of economic activity

Figure 2. Total funding to the participants of fishery sector divided according to the types of investment in the planning periods of 2004 - 2006, 2007 - 2013 and 2014 - 2020 (EUR million, \%) (author's calculations based on data from Finance Ministry, 2017; Rural Support Service, 2017).

the smallest: from the EAGGF with government cofunding $-0.21 \%$.

$52 \%$ of the total funding of EUR 161.35 million was channelled to 160 or $75 \%$ fishery companies, $28 \%$ of co-funding - to 14 associations, $16 \%$ of funding - to 10 various institutions (municipalities, port administrations, BIOR). Only $5 \%$ of the total funding was channelled to 552 or $50 \%$ of individual persons - in this case crew members of fishing vessels who lost their jobs as a result of decommissioning of fishing vessels.

As separate fishery companies are employed not only in fishing, but also fish processing, tourism, aquaculture and other types of economic activity, support of the EU funds was used also for the development of these fields (Figure 2).

The biggest funding (EUR 54.42 million or 34\%) was directed to the measures for structural adjustment of fishing fleet to the available fish resources. As a result of the support provided by the FIFG, EFF and ENFF, 242 fishing ships and boats were decommissioned, including scrapping or giving to non-profit purposes (79 fishing vessels in the framework of Fisheries Operational Programme (FOP) 2004 - 2006, 158 fishing vessels - FOP 2007 - 2013 and 5 fishing vessels - FOP 2014 -2020). As a result, the owners of the decommissioned fishing ships and boats received compensations in the amount of EUR 47.28 million, and the crew members of 552 fishing vessels who lost their jobs - in the amount of EUR 7.13 million.

Relatively big financing was channelled to modernization of fishing ports, wharves and discharging places - correspondingly EUR 35.87 million or $22 \%$ of the total funding. As a result of the support, wharves were restored, breakwaters were reconstructed, several unloading places and places for storing fishing equipment were modernized. Moreover, there were purchased inventory for fishing vessels and fishing equipment, different transfer facilities, ice machines and supply systems. Also different freezers and stands, sorting yards for fishing products and refrigerators were built, as well as other kind of equipment and machinery bought.

Funding of EUR 27.15 million or $17 \%$ was channelled to modernize the process of fish storing and processing. Within the framework of this funding, several activities took place: modernization of production units and processing workshops, purchase and installation of technological equipment and facilities, establishment of different chambers (quick freezer for fresh fish, fish curing establishment etc.) as well as modernization of the process of processing (introduction of new tin lids) and improvement of the territory.

The development of fishery producers' organizations also received important support. Funding in the amount of EUR 22.30 million or $14 \%$ was channelled to modernization of fishing ports and discharge places, the use of added value, product quality and bycatch, restoration of production, processing and marketing equipment and infrastructure. Furthermore, the funding was channelled to support storage, trade events (acquisition of certificates, participation in international exhibitions) and to cover the expenses related to the development and implementation of Production and trade plans (Table 1).

Funding in the amount of EUR 12.76 million or $8 \%$ was channelled to the development of aquaculture. Funding of EUR 5.29 million was directed to modernization of aquaculture processes (purchase of various equipment, formation of plants for fish farming and incubation, renovation of ponds, purchase of tractors, etc.), and EUR 7.47 million - to aquatic environment activities.

Acquisition of new markets and modernization of fishing fleet received funding in the amount of EUR 3.06 million and EUR 2.47 million, respectively, or $2 \%$. Funding of EUR 1.54 million or $1 \%$ was 
Total funding channelled to producers' organizations in the planning periods of $2004-2006$, 2007 - 2013 and 2014 - 2020 (EUR million,) (author's calculations based on data from

Finance Ministry, 2017; Rural Support Service, 2017)

\begin{tabular}{|c|c|c|c|c|c|}
\hline \multirow{3}{*}{ Type of investment } & \multicolumn{5}{|c|}{ Total finding } \\
\hline & \multicolumn{3}{|c|}{ Public } & \multirow{2}{*}{ Private } & \multirow{2}{*}{ TOTAL } \\
\hline & FIFG and country & EFF and country & EMFF and country & & \\
\hline Fishing ports and discharging places & - & 5.31 & 3.47 & 1.86 & 10.64 \\
\hline Added value, quality of products and use of bycatch & - & - & 5.29 & 1.76 & 7.05 \\
\hline $\begin{array}{l}\text { Investments into production, processing or marketing } \\
\text { equipment and infrastructure }\end{array}$ & - & 3.10 & - & 0.38 & 3.47 \\
\hline Storage support & - & - & 0.87 & - & 0.87 \\
\hline Trade events & - & - & 0.10 & 0.03 & 0.14 \\
\hline Production and trade plans & - & - & 0.08 & 0.03 & 0.11 \\
\hline Compensations of administrative expenses & 0.02 & - & - & - & 0.02 \\
\hline ( & 0.02 & 8.41 & 9.82 & 4.06 & 22.30 \\
\hline
\end{tabular}

allocated to the activities regarding eel stocking. Within the framework of the activities of FOP 2007 - 2013 "Renewal and development of villages where fishing activities take place", "Development of smallscale infrastructure and services related to fisheries and tourism", "Restructuring, reorientation of economic activities and diversification of activities" and the activity of Fisheries Operational Programme 2014 - 2020 "Implementation of community-led local development strategy", EUR 1.09 million or $1 \%$ of funding was directed to the development of the territories significant for fisheries.
Conversely, the least funding (EUR 0.71 million or $0.44 \%$ ) was channelled to the development of other economic activities, for example, agriculture, forestry, tourism, pig breeding, aviculture and electricity generation where the support was absorbed via EAGGF and ERDF.

CFP aims to ensure environmentally sustainable fish farms in the long-term performance as well as their management in accordance with the objective to ensure benefits in economic, social and employment sector, thus enhancing availability of food (European Parliament and Council, 2013). General objective

Table 2

Activities determined within the framework of the support of the FIFG, EFF and EMFF for the development of Latvian fishery sector (author's calculations based on data from Finance Ministry, 2003; Agriculture Ministry, 2007; 2014)

\begin{tabular}{|c|c|}
\hline FIFG support & EMFF support \\
\hline $20042005 \quad 20062007200820092010 \quad 20112012 \quad 2013$ & 32014201520162017201820192020 \\
\hline 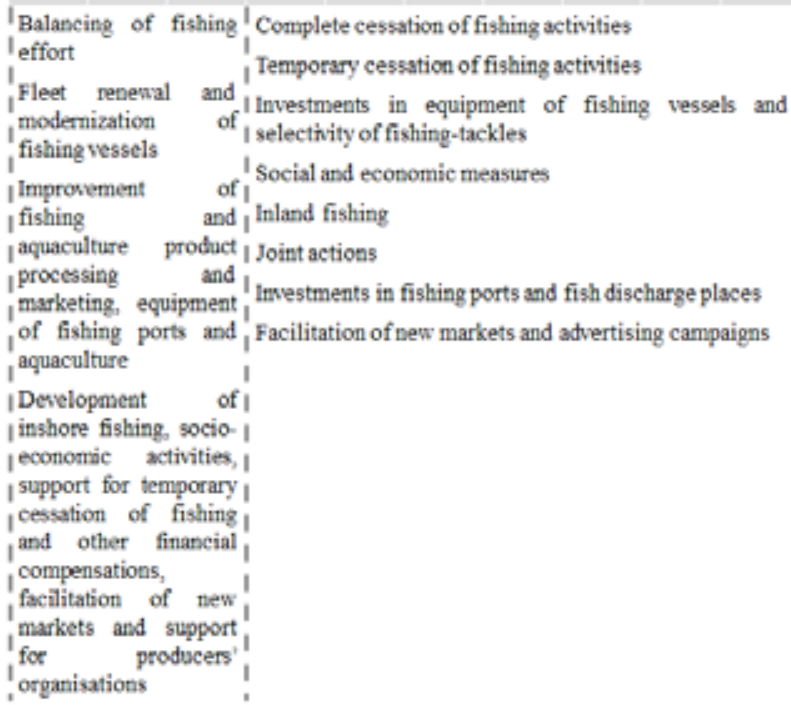 & 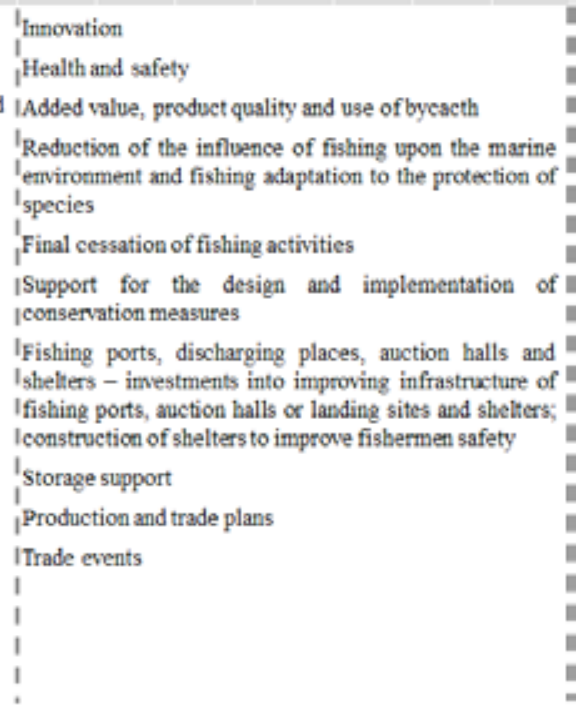 \\
\hline
\end{tabular}


of CFP is to ensure that fishing and aquaculture activities help with providing long-term sustainable environmental conditions necessary for economic and social development. Moreover, the directed policy should contribute to facilitating productivity, ensure sufficiently high standard of living to those who are employed in the fisheries sector and stable markets, as well as it should ensure availability of the resources and that products are available to consumers at reasonable prices (European Parliament and Council, 2014) (Table 2).

The policy of Latvian fisheries sector is a planned guiding by the framework established by CFP and the opportunities for facilitating sector's development, which thus requires highlighting of the main priorities at national level. The implementation of several activities was determined in order to facilitate the development of Latvian fishery sector via FIFG, EFF and EMFF.

On the basis of the analysis, it may be concluded that the participants of the fishery sector invested EUR 90.84 million or $56 \%$ of the funding in the development of their main activity, whereas EUR 16.10 million or $10 \%$ - in the facilitation of other spheres (development of territories significant for fisheries, eel stocking, development of aquaculture, etc.). Remaining funding in the amount of EUR 54.42 million or $34 \%$ was paid in the form of compensations for cessation of fishing activities. Contribution provided by the EU financial instruments reflects also in other indicators characterizing the development of the fisheries sector

\section{Overall situation in the Latvian fishery sector}

In 2016, 205 companies were operating in the Latvian fishery sector; 679 fishing vessels with a total engine power of 47.12 thousand $\mathrm{kW}$ and total gross tonnage of 28.52 thousand GT were at their disposal. Fishing fleet was composed of 12 vessels plying the high seas, 57 vessels fishing in the Baltic Sea and the Gulf of Riga beyond the coastline and 610 coastal fishing boats (Table 3).

Within the framework of FIFG, EFF and EMFF support, the activity for balancing of fishing vessel capacity with the available fish resources was implemented through the Fisheries Operational Programme. As a result, not only the number of fishing vessels $(-27 \%)$, their power $(-27 \%)$ and tonnage $(-26 \%)$, but also the number of the persons employed in the companies $(-37 \%)$ decreased in the period from 2005 to 2016 . The activity for balancing of fishing vessel capacity has enhanced the increase of the catch per fishing vessel and work productivity (respectively, by $4 \%$ and $180 \%$ ), which, in turn, has positively influenced the wages.

Although the amount of wages in the Latvian fisheries sector has multiplied by 3 since 2005 (to EUR 516 in 2016), it is still not competitive either in the local or the EU-28 labour market (the average net wage in Latvia in 2016 was EUR 631; the available data show that the average gross wage in EU-28 in 2013 was EUR 2242) (Central Statistical Bureau, 2018; Eurostat. Database, 2018). The employed labour may choose a job in another sector or abroad which is equivalent in terms of working conditions but offers

Table 3

Development of Latvian fishery sector from 2005 to 2016 (number, EUR, kW, GT, tons, \%) (author's calculations based on data from Agriculture Ministry, 2018; Central Statistical Bureau, 2018)

\begin{tabular}{|c|c|c|c|}
\hline Indicator & 2005 & 2016 & $\begin{array}{c}\text { Changes } \\
\text { (\%) }\end{array}$ \\
\hline Number of companies & 189 & 205 & 8 \\
\hline Number of fishing vessels & 928 & 679 & -27 \\
\hline Power of fishing vessels (thousand $\mathrm{kW}$ ) & 64.67 & 47.14 & -27 \\
\hline Tonnage of fishing vessels (GT) & 38.59 & 28.52 & -26 \\
\hline Number of employees & 1357 & 849 & -37 \\
\hline Average net wages (EUR) & 157 & 516 & 230 \\
\hline Work productivity (thousand EUR per & 828.13 & 2517.07 & 204 \\
\hline Catch per fishing vessel (tons) & 161.93 & 168.86 & 4 \\
\hline Catch (thousand tons) & 150.27 & 144.66 & -24 \\
\hline Catch value (million EUR) & 27.79 & 48.68 & 75 \\
\hline Balance of external trade (million EUR): & 1.84 & 14.90 & t 711 \\
\hline import (milj. EUR) & 1.12 & 1.05 & -6 \\
\hline export (mij. EUR) & 2.96 & 15.96 & 439 \\
\hline
\end{tabular}

Note. $\uparrow$ arrows indicate positive changes, $\downarrow$ arrows - negative changes, however, $\uparrow$ arrows show the changes of direct effects of FIFG, EFF and EMFF support. 
more competitive wages, thus raising additional risks in ensuring sector's competitiveness and its further development.

Provision of Common Fisheries Policy that at least $50 \%$ of the public funding (compensation) received within the framework of the activity of Fisheries Operational Programme must be invested in commercial activity, shall be evaluated positively (Ministers cabinet, 2008; 2015). Taking into account the support to this activity provided by FIFG, EFF and EMFF, approximately EUR 23.64 million were invested in the development of Latvian economy.

In 2016, the total catch constituted 114.66 thousand tons with a value of EUR 14.68 million. In state's territorial waters fishermen mainly caught sprat, herring and cod, but in the high seas - mainly horse-mackerel, pilchard, sardinella and mackerel. The catch was discharged in the territories of Latvian ports and outside them, as well as in the ports of other states.

Fishing opportunities of Latvia and fishing quotas in the Baltic Sea and the Gulf of Riga are based on the long-term research of environment and of fish resources at national and international level. Catch volumes of commercially significant and internationally controllable species depend on the quotas annually allocated to Latvia, which, in turn, depend on the state of the fish stocks. Environmental pollution, unfavourable spawning conditions, as well as intensive fishing and other factors have a negative influence upon the state of the fish stocks. As a result, in the Baltic Sea fishing quotas and the available fish raw materials decrease every year, and it has a negative influence not only on the activity of the fishing companies, but also on the fish processing companies. Due to stock fluctuations and changes in fishing opportunities allocated annually at the EU level, fishery companies have difficulties to plan their future activities.

Fishing quotas of Latvia have not been fully utilised thus far, and the main reasons are: restrictions on fishing-tackle usage regarding certain fish species, changeable hydro-meteorological conditions, and seasonal weather conditions which burden fishing or make it impossible (Latvian State Institute of Agrarian Economics, 2013).

Although the total catch has decreased since 2005 $(-24 \%)$, the catch value has increased significantly $(+75 \%)$. It indicates that the support provided by the EU financial instruments to modernization of fishing ports, wharves and discharging places and support to producers' organisations has improved the quality of fishing products and increased their added value, thus leaving a positive influence also on the balance of external trade. Fishing companies have managed to multiply export value by 5 (from EUR 2.96 million in 2005 to EUR 15.96 million in 2016), not increasing import at the same time.

Considering that fishery sector depends on fishing opportunities coordinated at the EU level and consistent with principles of sustainability, experts do not forecast growth of demand for vocational education in this sector in future (Latvian State Institute of Agrarian Economics, 2014). However, the potential of Latvian scientific institutions is sufficient to meet the needs of fishery sector in the innovation sphere. Currently several scientific institutions in Latvia are interested in collaboration in the sphere of innovations, enhancing their competence, if necessary (Latvian State Institute of Agrarian Economics, 2016).

Competitiveness and efficiency are identified as a driving force for sustainable development of fisheries. Taking into account that fishery sector depends on fishing opportunities coordinated at the EU level and consistent with the principles of sustainability, as well as intensified competition in global markets, strengthening of fishery competitiveness plays an important role.

\section{Conclusions}

In the planning periods of 2004-2006, 20072013 and 2014-2020, financial support of several EU financial instruments was available to the participants of the fishery sector. In this period the support was provided by EAGGF, ERDF, FIFG, EFF and EMFF in the amount of EUR 161.35 million, including the state and private co-funding. $75 \%$ of fishery companies and $50 \%$ of the employed in the companies, as well as different associations and institutions related to fishery sector received the support. Funding of EUR 90.84 million was channelled to the development of fishery sector and EUR 16.10 million - to the development of other fields. The remaining funding in the amount of EUR 54.42 million was received in the form of compensations for cessation of fishing activities.

From 2005 to 2016 in the fishery sector of Latvia the catch per fishing vessel and work productivity have increased, which, in turn, has positively influenced the wages. The funding invested into the fishery development provided the companies with an opportunity to improve the quality of fishing products, not increasing import at the same time, and exporting the product with a higher added value than it was done initially. The directed EU policy and the support provided within its framework by the EU financial instruments have facilitated the development of the fishery sector in Latvia. 


\section{References}

1. Agriculture Ministry (2007). Rīcības programma Eiropas Zivsaimniecības fonda atbalsta ieviešanai Latvijā 2007. - 2013. gadam (Operational Programme for the Latvian fisheries sector 2007 - 2013). 1pp. 107. (in Latvian).

2. Agriculture Ministry (2014). Rīcības programma zivsaimniecības attīstībai 2014. - 2020. gadam (Operational Programme for Development of Fisheries 2014 - 2020). 1pp. 138. (in Latvian).

3. Agriculture Ministry (2018). Latvijas zivsaimniecības integrētās kontroles un informācijas sistēma LZIKIS (Latvian Fisheries integrated control and information system LFICIS). Retrieved February 21, 2018, from: https://zikis.zm.gov.lv/Account/LogOn. (restricted access data). (in Latvian).

4. Central Statistical Bureau (2018). Database. Retrieved February 21, 2018, from: http://data.csb.gov.lv/ pxweb/en/?rxid=cdcb978c-22b0-416a-aacc-aa650d3e2ce0 (restricted access data).

5. European Commission (2014). Eiropas Jūrlietu un zivsaimniecības fonds Latvijā (European Maritime and Fisheries Fund in Latvia). Report summary. lpp. 4. (in Latvian).

6. European Parliament and Council (2013). European Parliament and Council Regulation (EU) No. 1380/2013 on the Common Fisheries Policy, amending Council Regulations (EC) No 1954/2003 and (EC) No 1224/2009 and repealing Council Regulations (EC) No 2371/2002 and (EC) No 639/2004 and Council Decision 2004/585/EC. Official Journal of the EU. 28.12.2013., L 354, p. 61.

7. European Parliament and Council (2014). European Parliament and Council Regulation (EU) No. 508/2014 on the European Maritime and Fisheries Fund and repealing Council Regulations (EC) No 2328/2003, (EC) No 861/2006, (EC) No 1198/2006 and (EC) No 791/2007 and Regulation (EU) No 1255/2011 of the European Parliament and of the Council. Official Journal of the EU. 20.05.2014., L 149, p. 66.

8. Eurostat (2018). Database. Retrieved February 21, 2018, from: http://ec.europa.eu/eurostat/data/database.

9. Finance Ministry (2003). Latvijas Attīstības plāns. Vienotais programmdokuments. 1.mērḳa programma 2004. - 2006. gadam (National Development Plan of Latvia. Single Programming Document for Latvia. Objective 1 Programme 2004 - 2006). lpp. 328. (in Latvian).

10. Finance Ministry (2017). Eiropas Savienības fondu vadības informācijas sistēma (Information system of the management of European Union funds). Retrieved August 28, 2017, from: https://vis.esfondi.lv. (restricted access data). (in Latvian).

11. Latvian State Institute of Agrarian Economics (2013). 3. Prioritārā virziena pasākumu 301. "Kopīgas rīcības pasākumi” un 303. "Investīcijas zvejas ostās un zivju izkraušanas vietās” investīciju atdeve (Return of investments of the 3rd priority direction activities 301 "Joint Action Activities" and 303 "Investments into fishing ports and fish discharging places”). Report. lpp. 72. (in Latvian).

12. Latvian State Institute of Agrarian Economics (2014). Stratēǵiskais ietekmes uz vidi novērtējums Eiropas Jūrlietu un Zivsaimniecības fonda Rīcības programmai 2014. - 2020. gadam (Evaluation of strategic influence on the environment for the Operational Programme of European Maritime and Fisheries Fund in 2014 - 2020). Environmental report. lpp. 73. (in Latvian).

13. Latvian State Institute of Agrarian Economics (2016). Latvijas zinātnisko institūciju iespējas inovāciju veicināšanā zivsaimniecībā (Possibilities of Latvian scientific institutions in facilitation of innovations in fisheries). Report. lpp. 45. (in Latvian).

14. Ministers cabinet (2008). MK noteikumi Nr. 323 Valsts un Eiropas Savienības atbalsta pieškiršanas kārtība zivsaimniecības attīstībai pasākumam 'Zvejas aktivitāšu pilnīga pārtraukšana' (Procedure of allocation of the state and European Union support for the fisheries development activity 'Complete cessation of fishing activities'). Latvijas Vēstnesis. 21.05.2008., No. 78 (3862) (in Latvian).

15. Ministers cabinet (2015). MK noteikumi Nr. 559 Valsts un Eiropas Savienības atbalsta piešķiršanas kārtība pasākumā 'Galīga zvejas darbību pārtraukšana' (Procedure of allocation of the state and European Union support for the activity 'Final cessation of fishing activities) Latvijas Véstnesis. 13.10.2015., No. 199 (5517), OP numurs: 2015/199.3 (in Latvian).

16. Rural Support Service (2017). Informatīvā sistēma (Informative system). Retrieved August 16, 2017 , from: http://lad.gov.lv/lv/. (restricted access data). (in Latvian).

17. World Wide Fund for Nature (2005). Clean Baltic within Reach? How can a new chemical policy contribute to the protection of the Baltic Sea? Report. p. 40. 